\title{
A controvérsia em torno da atribuição de cultura a animais não humanos: uma revisão crítica
}

\author{
Murillo Pagnotta \\ Briseida Dogo Resende \\ Universidade de São Paulo
}

\begin{abstract}
Resumo
Nas últimas décadas, estudiosos do comportamento têm afirmado que animais não humanos apresentam cultura, dando início a uma controvérsia, especialmente com antropólogos socioculturais, que ainda não foi resolvida. Com o objetivo de compreender melhor essa controvérsia e identificar possíveis direções de consenso, nós revisamos o desenvolvimento da noção de cultura na antropologia sociocultural e sua utilização na literatura etológica. Argumentamos que antropólogos socioculturais e estudiosos do comportamento animal divergem em termos de suas teorias e visões de mundo. Para alcançar uma abordagem sintética do comportamento animal que inclua humanos e não humanos, sem ignorar as características próprias de cada espécie, seria desejável construir um consenso nesses dois níveis. A questão dos símbolos e significados é central para a noção antropológica de cultura e, portanto, será necessário incluí-la em uma perspectiva comparativa. Concluímos que uma direção de consenso teórico encontra-se em abordagens críticas às dualidades natureza-cultura, inato-adquirido e gene-ambiente.
\end{abstract}

Palavras-chave: cultura; aprendizagem; desenvolvimento; etologia; antropologia.

\begin{abstract}
The controversy over the attribution of culture to nonhuman animals: A critical review. In recent decades, animal behaviorists have attributed culture to non-human animals, starting a controversy with socio-cultural anthropologists that is still far from cooling down. In order to better understand this controversy, and to identify possible paths that might lead to a consensus, we reviewed the meanings of the term culture as used by socio-cultural anthropologists, and also the history of its use in ethology (specially primatology). We argue that socio-cultural anthropologists and ethologists disagree in terms of their theories and worldviews. In order to reach a synthetic approach to human and non-human animal behavior, without ignoring speciestypical characteristics, it is desirable to search for consensus in both levels. The questions of symbols and of meanings are central to the anthropological notion of culture; therefore it will be necessary to discuss how to include them in a comparative perspective. We conclude that a direction of consensus may be found in theoretical approaches that are critical to the related dichotomies of nature-culture, innate-acquired and gene-environment.
\end{abstract}

Keywords: culture; learning; development; ethology; anthropology.

\section{Resumen}

La controversia alrededor de la atribución de cultura a animales no humanos: Una revisión crítica. En las últimas décadas, estudiosos del comportamiento han afirmado que animales no humanos presentan cultura, iniciándose una controversia, sobre todo con antropólogos socioculturales, que todavía no está resuelta. Con el objetivo de mejorar la comprensión de dicha controversia e identificar posibles direcciones de consenso, hemos revisado el desarrollo de la noción de la cultura en la antropología sociocultural y su utilización en la literatura etológica. Argumentamos que antropólogos socioculturales y estudiosos del comportamiento animal divergen en términos de sus teorías y visiones de mundo. Para alcanzar un abordaje sintético del comportamiento animal que incluya humanos y no humanos y sin ignorar las características propias de cada especie, sería deseable construir un consenso en estos dos niveles. La cuestión de los símbolos y significados es parte central de la noción antropológica de cultura y, por tanto, será necesario incluirla desde una perspectiva comparativa. Hemos concluído que una dirección de consenso teórico se encuentra en los abordajes críticos a las dualidades naturaleza-cultura, inato-adquirido y genético-medioambiental.

Palabras clave: cultura; aprendizaje; desarrollo; etología; antropología. 
provável que os antropólogos socioculturais concordem que os seres humanos são animais, e que é epistemologicamente legítimo estudar a morfologia, fisiologia e mesmo alguns aspectos comportamentais de nossa espécie utilizando os mesmos métodos, conceitos e compromissos filosóficos já consagrados no estudo de outros fenômenos biológicos. Mas, de acordo com a visão dominante nas ciências sociais, baseada em autores clássicos como Kroeber, White e Geertz, sempre sobra algo - relativo ao domínio da cultura - que, talvez por suas propriedades emergentes (Kroeber, 1917), ou talvez por seu fundamento simbólico (Geertz, 1973; White, 1949), escapa do domínio biológico, e deve ser investigado "em seus próprios termos". Nessa visão, os humanos não seriam apenas únicos, como qualquer outra espécie, mas únicos de uma maneira especial. Poderíamos argumentar que essa diferença se relaciona com o modo como o ambiente social em que crescemos influencia o nosso desenvolvimento e com as habilidades cognitivas (exclusivamente humanas?) que possibilitam tanto esse desenvolvimento individual quanto os fenômenos coletivos como a existência de diversas culturas e de história.

Por outro lado, as últimas décadas viram acumular evidências de que outras espécies animais também exibem diversidade comportamental entre populações, e que essa diversidade precisa ser explicada em termos de aprendizagem em contexto social. $\mathrm{O}$ termo cultura vem sendo utilizado para descrever esse fenômeno, especialmente em chimpanzés (Whiten et al., 1999), orangotangos (Van Schaik et al., 2003), cetáceos (Rendell \& Whitehead, 2001) e aves Grant \& Grant, 1996). Se aceitarmos que cultura não é um fenômeno exclusivo de nossa espécie, o comportamento humano estaria ainda mais próximo do arcabouço epistemológico utilizado pelas ciências biológicas para estudar o comportamento animal em geral. Além disso, ao menos alguns comportamentos de certos animais não humanos estariam também mais próximos do arcabouço epistemológico utilizado pelas ciências sociais. Mas, se o termo cultura descreve aquilo que torna os humanos únicos, qual seria o sentido de dizer que outros animais também possuem cultura? Como poderemos distinguir aquilo que nos singulariza, ao mesmo tempo em que reconhecemos nossa condição animal? Seria o caso de abandonar - ou talvez reconstruir - a velha separação acadêmica? Será possível encontrar um fundamento comum para as ciências naturais e sociais? O argumento clássico é que os humanos apresentam capacidades que os distinguem qualitativamente das demais espécies. Nesse sentido, o uso de símbolos e a construção cultural de significados poderiam ser entendidos como um comportamento típico da espécie humana. Não há dúvidas de que todas as espécies apresentam características próprias e, nesse caso, cabe distinguir o que há de semelhante e diferente entre a cultura humana e a "cultura" de outras espécies. Ainda assim, deve ser possível encontrar um fundamento epistemológico comum para compreender esses fenômenos - ao menos, esta é nossa aposta atual.

Nosso ponto de partida, nesta revisão, é a crença de que o diálogo e a busca ativa por um consenso são desejáveis e podem ser produtivas em ambas as direções. De acordo com esse possível caminho do meio, tanto cientistas sociais e naturais podem ter contribuições importantes e interessantes para atingirmos uma maior compreensão do comportamento animal (incluindo humanos). Para sermos claros, não estamos afirmando que esse arcabouço consensual precisaria incluir tudo de ambos os lados, ou que precisaria ser um tipo de "teoria sobre tudo". O que buscamos é uma base sólida que permitisse a investigação das coisas da natureza e das coisas da sociedade e da cultura sem precisarmos assumir essa dicotomia como inquestionável, e que permitisse compreender as continuidades e descontinuidades em diversos níveis de análise - e, portanto, entre diversas disciplinas. Isso pode demandar uma reconstrução radical de fundamentos teóricos, epistemológicos e filosóficos que se estabeleceram há muito tempo na tradição científica ocidental, e pode também exigir uma reconstrução radical de crenças, compromissos, preconceitos e motivações individuais e coletivas. Uma versão mais extensa do argumento desenvolvido a seguir pode ser encontrada em Pagnotta (2012).

Nesta revisão, investigamos os sentidos da noção de cultura para antropólogos socioculturais (daqui em diante, para facilitar a leitura, apenas "antropólogos") e estudiosos do comportamento animal não humano (apesar de o estudo do comportamento animal não humano incluir antropólogos, como na tradição norteamericana, utilizaremos o termo "etólogos" para nos referirmos a esses pesquisadores). Tivemos dois pontos de partida. Por um lado, revisamos os autores clássicos na história da antropologia, e incluímos autores contemporâneos que, a nosso ver, podem contribuir para o debate que estamos focando. Apesar de ser uma amostra representativa, nossa revisão não esgota a diversidade teórica existente na antropologia. Por outro lado, revisamos na literatura etológica o desenvolvimento do uso do termo cultura em relação a animais não humanos, desde os estudos pioneiros de Kinji Imanishi até o presente.

Em seguida, argumentamos que antropólogos e etólogos divergem em termos tanto de suas teorias quanto, numa perspectiva mais ampla, em termos de suas visões de mundo e que, para alcançar uma abordagem sintética do comportamento animal que inclua humanos e não humanos, seria desejável buscar construir um consenso nesses dois níveis. Há esforços partindo de ambos os lados em busca de mais diálogo. Por exemplo, no lado das ciências sociais, autores como Latour (1993) e Ingold (2000, 2004) mostram-se especialmente úteis para o debate atual, pois criticam a distinção natureza-cultura e buscam ferramentas teóricas e empíricas para lidar com ela, ou desfazer-se dela. Do outro lado, as inúmeras críticas feitas desde a década de 1950 (Gottlieb, 1992; Lehrman, 1953) ao conceito de instinto (proposto e defendido pelo etólogo Konrad Lorenz e seus alunos), à visão dualista de desenvolvimento que ela implica, e à linguagem da primazia causal dos gene em que ela se expressa (como na metáfora dos programas genéticos), também são centrais aqui.

Robert Hinde, por exemplo, acatou amplamente as críticas de Lehrman e, conjuntamente, editaram muitos números do periódico "Advances in the study of behavior". Para Hinde (1988) a ponte entre a abordagem social e naturalística seria construída a partir do reconhecimento de diferentes níveis de interação social (indivíduos, interações, relacionamentos e grupos). Mais recentemente, essas críticas se desdobraram, 
entre outras coisas, para estudos teóricos sobre as implicações evolutivas da construção de nicho (Odling-Smee, Laland, \& Feldman, 1996, 2003) e para a abordagem dos sistemas em desenvolvimento (Oyama, 1985; Oyama, Griffiths, \& Gray, 2001).

\section{Os sentidos da noção de cultura na antropologia}

Cultura tem origem no verbo latino colere, significando atividades diversas como habitar, proteger, adorar e cultivar (Williams, 1983). O sentido de habitar está presente no termo derivado colonus e em termos atuais como colônia. Com o sentido de adorar, colere derivou para cultus e para o termo atual culto (religioso). O significado de cultivar também se manteve, seja em um sentido físico, referindo-se ao cultivo do solo, como retido nos termos atuais agricultura e, metaforicamente, cultura de abelhas e cultura de células; seja em um sentido moral (através da metáfora de Cícero cultura animi), referindo-se à educação ou ao cultivo do espírito, e foi retido nos termos atuais culto (educado, erudito) e, no sentido que aqui nos interessa, cultura.

Foi na Alemanha, no entanto, que a noção de cultura começou a ganhar contornos mais próximos do seu sentido moderno. No século XVIII, o termo Cultur surgiu emprestado da França (e seria, a partir do século XIX, grafado Kultur) e foi inicialmente usado como sinônimo para o termo francês civilisation, referindo-se ao processo secular e progressivo de tornar-se civilizado ou cultivado, como descreviam os pensadores iluministas em suas histórias universais. Tratavase sempre do uso no singular, sendo que os diferentes povos poderiam se aproximar ou se afastar da Cultura, na medida em que fossem considerados mais ou menos civilizados.

No século seguinte, o humanista alemão Gustav Friedrich Klemm (1802-1867) identificava três estágios sucessivos no desenvolvimento da Cultura - selvageria, domesticação e liberdade -, utilizando o termo com o sentido que entraria oficialmente no discurso antropológico, com o britânico Edward Burnett Tylor (Williams,1983). No início de sua obra de 1871, Primitive Culture, Tylor estabeleceu a primeira definição formal ou explícita do termo cultura na antropologia, em que afirma ser a cultura "um todo complexo", indicando a seguir uma lista de traços: "Cultura ou civilização, em seu amplo sentido etnográfico, é aquele todo complexo que inclui conhecimento, crença, arte, moral, lei, costume e quaisquer outras capacidades e hábitos adquiridos pelo homem como membro da sociedade." [tradução dos autores] (Tylor, 1871/1874, p. 1).

Essa definição exerceu enorme influência em definições posteriores, e seu objetivo é menos propor uma hipótese a ser testada do que definir um campo de investigação listando os comportamentos de interesse (Washburn \& Benedict, 1979).

Ainda no século XVIII, o filósofo humanista alemão Johann Gottfried von Herder (1744-1803) criticou a primazia da cultura europeia, para não dizer francesa, que era vista como telos de um desenvolvimento universal. Em sua obra Ideen zur Philosophie der Geschichte der Menschheit, publicada em vinte volumes entre 1784-1791, Herder (citado por Williams, 1983) demonstra uma ausência de etnocentrismo tão incomum para a época que sua leitura vale a pena:
Homens de todos os cantos do globo, que pereceram ao longo das eras, vós não vivestes somente para adubar a terra com vossas cinzas, para que no fim dos tempos vossa posteridade fosse agraciada pela cultura europeia. O próprio pensamento de uma cultura europeia superior é um insulto grosseiro à majestade da Natureza. [tradução dos autores] (Willian, 1983, p. 89).

Herder utilizava o termo cultura para indicar o modo de vida e os valores espirituais particulares de um povo (e de uma época) e que o distinguem de seus vizinhos (e de outras épocas). Propôs então o seu uso no plural, referindo-se às variadas culturas de diferentes nações e mesmo de grupos sociais e econômicos no interior de uma nação. Esse uso do termo foi desenvolvido no Romantismo alemão como alternativa à ideia francesa de civilização, enfatizando as culturas tradicionais e nacionais em oposição a uma suposta Cultura ou civilização universal e ao materialismo do desenvolvimento industrial (Williams, 1983). No final do século XIX, Franz Boas, formado no pensamento alemão, desenvolveria esse sentido na Antropologia Cultural norte-americana (Boas, 1940), e esse uso no plural (as culturas dos povos, ao invés de uma cultura universal) constitui o fundamento do sentido moderno do termo (Barnard \& Spencer, 2005).

Em 1952, dois eminentes antropólogos americanos, Alfred Louis Kroeber e Clyde Kluckhohn publicaram uma extensa revisão das teorias antropológicas. Esses autores verificaram que, depois de Tylor, trinta e dois anos passariam até que surgisse uma segunda definição explícita para cultura na literatura antropológica, em 1903. Entre 1903 e 1919, identificaram seis definições formais e, entre 1920 e 1950, outras 157. Depois de rever estas 164 definições e outras centenas de proposições sobre cultura (isto é, trechos de obras que discorrem explicitamente sobre o tema, apesar de não serem definições formais), os autores concluem que, se não havia uma teoria completa sobre cultura na antropologia, existia ao menos um "conceito razoavelmente bem delineado" (Kroeber \& Kluckhohn, 1952, p. 181).

Segundo essa concepção, uma das características da cultura é o fato de ser exclusividade da espécie humana em sua vida em sociedade. Esse privilégio estaria garantido pela nossa (também exclusiva, segundo eles) capacidade de utilizar símbolos. A importância do uso de símbolos (por exemplo, no uso de linguagem articulada) como aquilo que distingue os humanos de outros animais foi bastante enfatizado pelo antropólogo neo-evolucionista americano Leslie White, como vemos em sua própria definição de cultura:

\footnotetext{
"cultura" é o nome de uma ordem, ou classe, distinta de fenômenos, quais sejam, as coisas e eventos que dependem do exercício de uma habilidade mental, peculiar à espécie humana, que nós denominamos "simbolização". Mais especificamente, cultura consiste em objetos materiais - ferramentas, utensílios, ornamentos, amuletos, etc. - atos, crenças e atitudes que funcionam em contextos caracterizados pela simbolização. Trata-se de um mecanismo elaborado, uma organização de modos e meios exossomáticos empregados por uma espécie animal em particular, o homem, na luta pela existência e sobrevivência. [tradução dos autores] (White, 1949, p. 363).
} 
Mas a importância do caráter simbólico do comportamento humano está longe de ser uma ideia exclusiva desse antropólogo, e talvez seja mesmo um dos únicos consensos no interior da disciplina, especialmente depois da virada interpretativa capitalizada por Clifford Geertz e outros expoentes da Antropologia Simbólica, a partir dos anos 1960. O exemplo paradigmático de uso de símbolos é a fala, mas um símbolo pode ser um objeto, uma cor, um som, um odor, um tipo de movimento, um sabor - enfim, pode assumir qualquer forma física - cujo sentido ou valor não deriva de suas propriedades intrínsecas, mas é conferido pelos organismos que o reconhecem e o utilizam como tal (White, 1949).

Na tradição americana, muitos antropólogos defenderam, a partir do ensaio "The Superorganic", de Kroeber (1917) que os fenômenos culturais são emergentes e correspondem a um nível de análise próprio, acima do biológico - extrassomático, exossomático e superorgânico são termos usados em sua descrição (Kroeber \& Kluckhohn, 1952). A questão não é que a biologia não seja importante para o estudo do comportamento humano; o que está implícito é o pressuposto de que as populações humanas não apresentam variações biológicas e psicológicas importantes e que, portanto, as variações comportamentais entre grupos devem ser antes explicadas em termos de aprendizagem e história (Washburn \& Benedict, 1979). Em outras palavras, o que essa visão defende, contra abordagens racistas que haviam dominado a antropologia em sua formação, é que as diferenças nos fenômenos culturais não podem ser reduzidas a diferenças em fatores subvenientes biológicos (raciais) ou psicológicos (Barnard \& Spencer, 2005).

Quando observamos diretamente o comportamento de indivíduos, não se trata ainda de cultura. Embora pressuposto para a sua existência, cultura não é comportamento, mas padrões abstraídos de comportamentos individuais (Kroeber \& Kluckhohn, 1952). A cultura de um grupo pode ser entendida num sentido descritivo, quando se refere a padrões observados de comportamento, ou num sentido normativo, enquanto regras explícitas ou implícitas que ditam e constrangem o comportamento individual e coletivo. Além disso, também se manifesta em objetos materiais, ideias e valores. Na verdade, os valores associados a objetos, ideias, práticas, etc., são fundamentais para a noção moderna de cultura, pois são eles que fundamentam toda a organização de uma cultura particular, oferecendo um eixo em torno do qual o "todo complexo" se organiza.

Outra característica da cultura de qualquer povo é o fato de ela não ser algo estático, mas acumular mudanças históricas ao longo das gerações. A ideia de cultura como herança social historicamente cumulativa e transmitida por tradição é explicitamente mencionada em trinta e três das definições listadas em Kroeber e Kluckhohn (1952).

Essa concepção antropológica de cultura, sistematizada por Kroeber e Kluckhohn (1952), fundamenta-se em uma distinção dualista entre natureza (ou biologia) e cultura que foi, até recentemente, um dogma central na antropologia (Descola \& Pálsson, 1996; Ingold, 2000). Mas essa distinção, e a epistemologia que a sustenta, tem sido alvo de crítica e intenso debate a partir de diferentes frentes. Com sua Antropologia
Estrutural, Lévi-Strauss (1952/1974) estabeleceu um método para investigar as estruturas cognitivas que estão por trás de inúmeros aspectos do comportamento humano, em que a função simbólica do pensamento humano é logicamente fundamental.

Clifford Geertz (e a tradição da Antropologia Simbólica) abandonou a ideia de cultura como uma realidade superorgânica, como padrões e regras abstraídas de comportamento, e propôs uma definição semiótica segundo a qual cultura é a rede de significados, ou sistemas de símbolos públicos, que as pessoas utilizam para conferir sentido às suas experiências e para guiar seu comportamento (Geertz, 1973).

Tim Ingold defende o que chama de "pensamento relacional', e está explicitamente interessado no diálogo com as ciências biológicas. Ele concebe cultura como habilidades (motoras, sensoriais e inclusive simbólicas) incorporadas no desenvolvimento de cada organismo humano, e enfatiza a necessidade de olhar para o desenvolvimento, e de romper com as distinções entre genótipo e fenótipo, entre inato e aprendido, que ainda persistem na biologia (Ingold, 2000, 2004).

As ideias da antropologia sobre o tema da cultura se desenvolveram para direções variadas desde a década de 1950 e não há, atualmente, um fundamento teórico comum a todos esses ramos. No entanto, existe uma ideia compartilhada por virtualmente todos os antropólogos citados e que talvez seja um dos poucos consensos existentes. Trata-se do aspecto simbólico exibido pelo comportamento humano. Portanto, no diálogo entre etólogos e antropólogos, seria desejável compreender melhor o que significa essa capacidade simbólica e buscar meios de conceituá-la que permitam investigá-la em uma perspectiva comparativa.

Para sintetizar, podemos afirmar que, em termos gerais, a palavra cultura evoca nos antropólogos socioculturais (1) a capacidade de criar, manipular e compartilhar símbolos incluindo símbolos linguísticos -, que permitem e regulam (2) a existência de padrões compartilhados de comportamentos, significados e maneiras de atuar no ambiente, que (3) dependem de aprendizagem em contexto social para se desenvolver em cada pessoa e em sucessivas gerações.

\section{O uso recente do termo cultura entre etólogos}

Talvez não seja surpresa que a história de atribuição de cultura a não humanos tenha iniciado bem longe da Europa tanto em termos geográficos quanto filosóficos. O pesquisador japonês Kinji Imanishi (1902-2002), fundador da primatologia no Japão, cresceu em um contexto budista. De acordo com essa tradição, a vida é um ciclo eterno em que uma pessoa pode renascer na forma de qualquer animal; da mesma forma, qualquer animal pode renascer como um ser humano em uma próxima vida. Imanishi não acreditava na separação radical entre os humanos e outras espécies: "não podemos considerar os animais como meros autômatos, nem os humanos como criações especiais de uma divindade onipotente e onisciente" [tradução dos autores] (Imanishi, 1941/2002, p. 6). Ao invés disso, enfatizava a unidade e a harmonia da natureza (incluindo os humanos), o sistema integrado e inseparável formado pelo organismo e seu ambiente, e a necessidade de reconhecer a existência simultânea de semelhanças e diferenças entre as 
coisas e fenômenos.

Imanishi não via problemas em considerar os humanos como outra espécie animal: "Isso nem relega os humanos a um nível animal nem eleva os animais a um nível humano, mas nos permite discutir ambos sobre o mesmo fundamento" (Imanishi, 1941/2002, p. 4).

Em um ensaio escrito em 1952 (em japonês e sem tradução disponível), Imanishi (1952, citado por Nakamura \& Nishida, 2006) argumentou que outros animais poderiam exibir algo semelhante à cultura. Mas ao invés de utilizar bunka (o termo japonês usualmente traduzido por cultura), ele cunhou um novo termo baseado no som da palavra em inglês culture: kaluchua. De acordo com seus alunos, "[Imanishi] disse que kaluchua era mais amplo do que bunka e significava comportamento não hereditário, adquirido e reconhecido socialmente" [tradução dos autores] (Nakamura \& Nishida, 2006, p. 35).

Foi por sua convicção de que o estudo comparativo nos ajudaria a traçar a evolução da sociedade humana que Imanishi decidiu investigar o comportamento de outras espécies, utilizando métodos da sociologia, com identificação individual e longas observações de suas relações sociais. Depois da Segunda Grande Guerra, ao retornar da Mongólia onde tinha estudado cavalos selvagens, Imanishi decidiu estudar os macacos japoneses (Macaca fuscata) na ilha de Koshima.

A habituação com o fornecimento de alimentos foi iniciada em 1952. Em Setembro de 1953, Satsue Mito, uma jovem assistente local, relatou aos pesquisadores que tinha visto uma macaca levar batata-doce (um dos alimentos oferecidos) até um corpo d'água próximo e lavar a areia que a cobria antes de comê-la (por esse motivo ela passaria a ser chamada de Imo, "batata doce" em japonês). O desenvolvimento e a dispersão desse comportamento para outros indivíduos foram cuidadosamente registrados ao longo dos anos que se seguiram (revisões mais recentes em Hirata, Watanabe, \& Kawai, 2001; Matsuzawa, 2003; Nishida, 1987). Sob influência de Imanishi, os primeiros artigos, escritos em japonês, utilizam o termo kaluchua (Nakamura \& Nishida, 2006).

Em 1958, depois de ter estado na África para um estudo preliminar com gorilas, Imanishi viajou pelos EUA, onde se encontrou com diversos pesquisadores, entre eles os antropólogos Clyde Kluckhohn e Sherwood Washburn, com quem discutiu sobre as observações em Koshima e a questão da possibilidade de cultura em animais não humanos.

A mesma precaução que tinha justificado o uso do neologismo também explica o uso de prefixos nos primeiros artigos escritos em inglês: "sub-culture" (Kawamura, 1959) e "preculture" (Kawai, 1965). Mais tarde, Kawai explicaria que os prefixos indicavam o reconhecimento da existência de diferenças, ao mesmo tempo em que defendiam uma abordagem comparativa: "Não devemos superestimar a situação e dizer que 'macacos possuem cultura' e então confundi-la com cultura humana" [ tradução dos autores] (Hirata et al., 2001, p. 490).

Os estudos de campo na África, começando nos anos 1960 com Imanishi, Jane Goodall e outros, revelaram que o comportamento dos chimpanzés, a espécie mais próxima dos humanos, era muito mais complexo, diverso e semelhante ao comportamento humano (ou, inversamente, que o comportamento humano era muito mais semelhante ao comportamento de outros primatas) do que jamais se tinha concebido. Gradualmente, os primatólogos aprenderam que os chimpanzés vivem em unidades sociais (ou comunidades) em que estabelecem relações sociais que duram toda a vida (Nishida, 1968); utilizam diversas ferramentas cotidianamente (Goodall, 1964), incluindo, em algumas populações, martelos e bigornas para abrir frutos duros (Boesch \& Boesch, 1981, 1984); caçam coletivamente (Boesch \& Boesch, 1989); e talvez até mesmo ensinem ativamente os juvenis em certas circunstâncias (Boesch, 1991).

Em 1975, William McGrew e Caroline Tutin estiveram nas montanhas de Mahale (no sítio coordenado por Junichiro Itani, antigo aluno de Imanishi), onde observaram um comportamento peculiar de catação (o aperto de mão com catação ou grooming hand-clasp), que nunca tinha sido observado entre os animais de Gombe (sítio liderado por Jane Goodall), a apenas $50 \mathrm{~km}$ dali. Naquele tempo, o termo "tradição" já estava estabelecido na etologia, e era utilizado para se referir a diferenças comportamentais entre populações que não podiam ser explicadas em termos de diferenças genéticas ou ecológicas (Galef, 2006). Os exemplos mais bem conhecidos à época eram explicitamente dirigidos a recursos materiais (por exemplo, forrageamento). Mas o comportamento observado em Mahale parecia ser uma tradição social arbitrária sem qualquer relação com o uso de recursos materiais. O artigo que o descreve (McGrew \& Tutin, 1978) foi o primeiro, na literatura etológica ocidental, a discutir explicitamente a relação entre cultura humana e tradições não humanas.

De acordo com a literatura etológica da época, havia três possíveis explicações para a diferença comportamental entre as duas populações: ela poderia ser devido a (1) alguma diferença genética, (2) repostas diversas aprendidas individualmente a diferentes condições ambientais enfrentadas pelas duas populações, ou (3) emergência de padrões compartilhados de comportamento a partir de aprendizagem em contexto social. McGrew e Tutin (1978) decidem pela terceira hipótese e perguntam: "Essas tradições sociais em animais satisfazem critérios antropológicos aceitos, de modo que pudessem ser chamadas de culturais?" [tradução dos autores] (McGrew \& Tutin, 1978, p. 242). Eles também defendem a necessidade de uma definição operacional de cultura, que estipulasse propriedades empiricamente observáveis e mensuráveis, e que afirmasse as condições necessárias e suficientes para um fenômeno ser considerado cultural. Em sua conclusão, os autores defendem a legitimidade de utilizar o termo cultura (depois de o redefinirem) em relação aos chimpanzés.

$\mathrm{O}$ artigo teve relativamente pouco impacto imediato. Os antropólogos Sherwood Washburn e Burton Benedict responderam que, apesar das semelhanças, a linguagem simbólica torna a cultura humana algo único, e que o termo deveria ser utilizado exclusivamente em relação à nossa espécie (Washburn \& Benedict, 1979). Anos depois, o antropólogo Tim Ingold diria a McGrew algo semelhante: "É possível que os antropólogos socioculturais não estejam dispostos a atribuir cultura aos chimpanzés até que, e a não ser que, se demonstre que os atos dos antropoides têm algum significado para eles" [tradução dos autores] (Ingold, comunicação pessoal citada 
em McGrew, 1992, p. 86, itálico no original). Símbolos e significados existiriam apenas através de interações discursivas humanas. McGrew (2003, 2004) continuou a discussão com a antropologia, argumentando pela dissociação entre cultura e linguagem e a favor de seu uso em relação a animais não humanos.

A tese de que a habilidade linguística humana exibe características únicas, que por sua vez afetam virtualmente todos os aspectos do comportamento (cultural) humano, não é muito problemática, e pode mesmo ser considerada uma observação empírica com a qual cientistas sociais e naturais provavelmente concordariam. Mas se humanos são animais, então o comportamento comunicativo humano, mesmo o comportamento comunicativo simbólico, é uma variedade do comportamento comunicativo animal, e não algo completamente distinto.

Não queremos com isso dizer que os cientistas sociais estão enganados a esse respeito. Pode muito bem ser o caso que a comunicação simbólica torne o nosso comportamento algo tão complexo que é impossível compreendê-lo utilizando apenas as ferramentas e teorias da etologia. Pode ser o caso que as interações sociais humanas apresentam propriedades emergentes que precisam ser investigadas em um nível distinto de análise, com novos conceitos e métodos - como sugerem a história da antropologia e da sociologia. Nosso ponto é que, mesmo nesse caso, deve ser possível encontrar um arcabouço epistemológico e teórico comum. Afinal, se todos concordam que os humanos são uma espécie animal, então o estudo do comportamento humano é parte do estudo do comportamento animal - pode ser uma parte especial, mas ainda assim não independente.

A investigação dos chamados comportamentos culturais em animais não humanos como primatas, aves, cetáceos e roedores cresceu na etologia, apesar da falta de consenso sobre o uso do termo cultura para descrevê-los (para um panorama de diferentes posicionamentos, veja Laland \& Galef, 2009). Novamente, se prestarmos mais atenção às semelhanças do que às diferenças entre esses autores (e, em comparação com os antropólogos, há muito menos diferenças), podemos dizer que, entre os etólogos, o termo cultura evoca (1) a existência de padrões de comportamentos compartilhados entre membros de um grupo e (2) que dependem de aprendizagem em contexto social para se desenvolver.

Comparando as proposições que apresentamos para antropólogos e etólogos, verifica-se que a questão dos símbolos, da linguagem e do significado é central para os antropólogos, mas está ausente entre os etólogos. Para que o termo pudesse ser aplicado igualmente a humanos e não humanos, os etólogos lidaram com essa questão desfazendo - por definição - a relação entre cultura e linguagem simbólica. Portanto, etólogos, psicólogos e antropólogos compartilham o significante, mas não o significado, e o uso do termo cultura por uns e outros nem se refere ao mesmo conceito, nem implica a existência de teorias consensuais do comportamento. Ao menos nesse estágio da controvérsia, a redefinição do termo tornou-o fundamentalmente incompatível com o sentido antropológico. Concluímos que é necessário lidar com a questão dos símbolos e dos significados de modo comparativo (e, portanto, evolutivo), se desejamos chegar a um consenso sobre (1) como definir cultura; (2) se a sua extensão (i.e., o número de espécies a que pode se referir) deve ser mesmo expandida; (3) se for este o caso, como podemos explicar as semelhanças e diferenças entre a cultura de humanos, chimpanzés, ratos, baleias, ou qualquer outra espécie; ou mesmo (4) se o termo deveria ser completamente abandonado - quiçá mesmo em relação aos seres humanos! À primeira vista, pode parecer tratar-se de uma simples questão de definição. Mas a situação é mais complicada, como argumentamos a seguir.

\section{Conceitos de cultura na antropologia e na etologia: semelhanças e diferenças}

$\mathrm{Na}$ tentativa de conseguirmos indicar direções para a construção de consenso, vamos olhar para as semelhanças e diferenças entre os autores dos dois lados da controvérsia, em termos de suas teorias e visões de mundo. Para cada um desses níveis de elaboração epistêmica, distinguiremos duas alternativas antagônicas gerais que se encontram na literatura.

Quanto às visões de mundo, a primeira alternativa afirma que o termo cultura deve ser compreendido como parte de uma dualidade, natureza-cultura, que expressa a ideia de que os humanos são fundamentalmente distintos do resto da natureza, e que os fenômenos culturais (humanos) devem ser investigados por disciplinas (antropologia, sociologia) que são relativamente independentes da biologia e da psicologia. A maioria dos antropólogos, desde as origens da disciplina no século dezenove até os anos 1960, se encaixa bem nessa descrição (Kroeber \& Kluckhohn, 1952). Na verdade, a enorme maioria dos filósofos e dos naturalistas, desde Aristóteles até o século dezenove, também se enquadram aqui. Foi apenas com a consolidação das teorias evolutivas de Charles Darwin que a ideia de singularidade humana começou a ser seriamente questionada dentro das ciências naturais.

A visão de mundo alternativa a esta afirma que os humanos não são fundamentalmente distintos dos outros animais, e que o estudo do comportamento humano é parte do estudo do comportamento animal. Portanto, seria legítimo investigar os fenômenos culturais humanos a partir de uma perspectiva comparativa e evolutiva, fundamentada em teorias consistentes com o que já está consolidado como consensual na biologia e na psicologia comparada. Esta visão é defendida (com diferenças) por virtualmente todos os etólogos e também por antropólogos socioculturais como Ingold (2000).

Quanto às teorias, o termo cultura se refere à maneira como descrevemos, investigamos e explicamos os comportamentos de humanos e de outros animais. Na primeira alternativa, existe uma visão dualista da ontogenia: alguns comportamentos se desenvolvem de modo relativamente independente dos fatores ambientais (talvez a partir de "programas genéticos"), enquanto outros se desenvolvem a partir da interação entre o organismo (alguns diriam “entre os genes") e fatores do ambiente, mas ainda assim sob controle primordial dos genes, o que fica explícito com o conceito de "norma de reação". Essa orientação teórica geral em relação às origens do comportamento (na verdade, de todos os aspectos do fenótipo) é historicamente hegemônica entre a maioria dos autores das ciências naturais e também está presente em cientistas sociais (Por ex., Geertz, 1973). 
Um dos efeitos colaterais do desenvolvimento da Genética e da síntese evolutiva na primeira metade do século vinte foi a hipertrofia dessa visão dualista, a partir da consolidação do gene como entidade material que sustentaria a noção de hereditariedade e que governaria a ontogenia. Com isso, muitos pesquisadores se sentiram à vontade para ignorar a complexidade do desenvolvimento ou considerá-lo uma caixapreta em suas análises evolutivas (Dawkins, 1989). Essa outra dualidade, gene-ambiente, expressa um compromisso com uma visão também hegemônica dentro das ciências biológicas que implica que (1) a herança é restrita aos genes; (2) o fenótipo é o resultado da interação de duas fontes causais ontologicamente distintas (como expresso na fórmula fenótipo $=$ genótipo + ambiente); (3) a primazia causal no desenvolvimento está nos genes (que "codificam programas" que são "expressos" no desenvolvimento); e, uma vez que apenas os genes são considerados como fatores herdados, (4) a evolução é equivalente a mudança nas frequências gênicas.

Paralelamente, a ideia de unidade psíquica da humanidade - isto é, que as diferentes populações humanas não apresentam diferenças cognitivas significativas, e que a diversidade comportamental (cultural) deve ser explicada em termos de diferenças no contexto de desenvolvimento, aprendizagem social e história - está no fundamento da noção antropológica moderna de cultura e, portanto, da dicotomia natureza-cultura (Ingold, 2004). Uma vez que o substrato material da mente é o cérebro, essa doutrina é consistente com a visão dualista de desenvolvimento: as estruturas e o funcionamento gerais do cérebro são "inatos" e essencialmente os mesmos em todas as pessoas, mas os conteúdos específicos e as habilidades específicas são "adquiridos” em cada ontogenia, no desenrolar da interação com a cultura específica do grupo em que o indivíduo cresce. Em termos mais recentes, se conferimos aos genes a primazia causal no desenvolvimento, então a estrutura (ou forma) é atribuída à expressão dos programas genéticos, e as habilidades (ou conteúdos) culturais específicos são atribuídas ao ambiente contingente de desenvolvimento. Nessa perspectiva, uma vez que a evolução biológica é definida como mudanças nas frequências alélicas, ela se distingue da história, que se refere às mudanças sociais e culturais que supostamente ocorrem sem alteração do substrato biológico (Ingold, 1998).

Ainda não existe um arcabouço teórico consensual em oposição a essa orientação hegemônica. Mas existe um acúmulo, especialmente nas últimas décadas, de críticas, propostas e tentativas de encontrar alternativas a esta visão genecêntrica e dualista do desenvolvimento. Por exemplo, as críticas à dicotomia entre inato e adquirido, e o reconhecimento da complexidade do desenvolvimento comportamental, já se tornaram discussões clássicas na psicologia (Gottlieb, 1992; Kuo, 1967; Lehrman, 1953; Schneirla, 1956).

Por sua vez, Gibson (1979) defendeu uma abordagem ecológica para a psicologia fundamentada na unidade entre organismo e ambiente. Para Gibson, o conceito de affordance (termo por ele cunhado) é central para explicar o comportamento de um animal. Affordances pode ser entendido como aquilo que o animal é capaz de perceber (e percebe agindo) das possibilidades de ação apresentadas pelos corpos, objetos e outros elementos presentes em seu ambiente. O organismo não está separado do ambiente, passivamente recebendo estímulos que ele, em seguida, precisa processar (como na metáfora do computador, ainda hegemônica nas ciências cognitivas). Ao invés disso, mesmo a percepção é entendida como uma exploração ativa dos padrões de energia (som, luz, etc.) que estruturam e definem o que é o ambiente para cada organismo. A partir dessa atividade, o organismo aprende a sintonizar os aspectos relevantes do ambiente. A unidade de análise, portanto, é o sistema formado pelo organismo e seu ambiente.

Outra contribuição que tem se mostrado produtiva é o argumento de Lewontin (1983) a respeito da relação entre o organismo e o seu ambiente. Segundo este autor, o organismo não é apenas passivo em relação às pressões seletivas do ambiente, mas também é capaz de construir, com sua própria atividade, parte do ambiente em que vive. Portanto, os organismos são capazes de alterar a pressão seletiva a que estão submetidos, e assim influenciar os rumos da evolução. Essa reciprocidade não é reconhecida nas análises evolutivas tradicionais. Mais recentemente, essa crítica foi o ponto de partida para a ideia de construção de nicho (Odling-Smee et al., 1996, 2003). Esses autores exploram, a partir de modelos matemáticos, as consequências evolutivas da construção recíproca de organismo e seu ambiente.

Além disso, a ênfase nos genes nas análises de desenvolvimento e evolução tem sido questionada pela abordagem dos sistemas em desenvolvimento (Griffiths \& Gray, 1994; Oyama, 1985, 2000). Segundo essa perspectiva, o organismo (fenótipo) emerge num sistema de elementos e processos em interação que incluem aspectos internos e externos ao corpo e em diversos níveis de escala espaço/temporal (de moléculas a interações ecológicas e sociais). Nessa visão a complexidade do desenvolvimento é posta em primeiro plano, não deixando espaço para a metáfora de programa genético. Com relação à herança (conceito que explica a manutenção da forma entre gerações, usualmente identificado com herança genética), esses autores enfatizam que não apenas DNA, mas diversos outros fatores - incluindo fatores epigenéticos, comportamentos e informação simbólica - são "transmitidos", ou estão disponíveis, entre gerações. Por isso defendem a ampliação do conceito de herança e avaliam as consequências teóricas dessa ampliação (Jablonka \& Lamb, 2005; Odling-Smee, 2007; Oyama, 1985). Outras contribuições nesta direção podem ser encontradas no volume editado por Oyama et al. (2001).

O que todos esses autores têm em comum é (1) uma maior ênfase nos processos de desenvolvimento, (2) uma rejeição da dicotomia entre inato e adquirido, ou instinto e aprendizagem, (3) uma crítica à primazia causal do gene e (4) o reconhecimento da relação fundamental entre organismo e o seu ambiente. Mas essas semelhanças não implicam que haja homogeneidade teórica ou uma única escola coerente e estabelecida.

\section{Direções para um consenso}

Alcançar uma abordagem sintética para o estudo do comportamento dependerá de construirmos um consenso com relação (1) à visão de mundo geral, relativa à distinção entre humanos e não humanos, e (2) às teorias utilizadas 
para descrever, investigar e explicar o desenvolvimento do comportamento de humanos e não humanos, independentemente de utilizarmos o termo cultura.

Virtualmente todos concordam (ao menos hoje em dia) que humanos são animais. Portanto, é provável que o consenso seja fundamentado em uma visão de mundo que não distingue os humanos como seres especiais, privilegiados por serem os únicos a serem algo a mais do que "apenas" animais. Também, uma vez que existe um consenso crescente entre cientistas naturais e sociais da inadequação das dicotomias inato-adquirido e gene-ambiente, é provável que o consenso seja fundamentado em teorias que não fazem uso dessas dualidades no estudo do comportamento e seu desenvolvimento.

Se esse argumento é válido, segue que os antropólogos socioculturais interessados na construção desse consenso terão que dialogar com a possibilidade de investigar o comportamento humano em uma abordagem comparativa e, portanto, evolutiva. Afinal, afirmar simultaneamente que humanos são animais e que o estudo do comportamento humano é independente da biologia é, para dizer o mínimo, incoerente. Por outro lado, os etólogos interessados na construção desse consenso terão que considerar explicitamente tanto as semelhanças quanto as diferenças entre o comportamento (cultural) em humanos e não humanos, e prestar atenção ao que os cientistas sociais têm a dizer. Eles também terão que continuar desenvolvendo alternativas teóricas à já criticada distinção entre inato e adquirido, e investigar a ontogenia dos comportamentos sem atribuir primazia aos genes, reconhecendo a construção recíproca do organismo e seu ambiente. Também será imprescindível incluir a questão simbólica nesse diálogo.

Os animais não humanos apresentam cultura? A resposta a essa pergunta depende, é claro, de como se define o termo controverso. Neste artigo, ao invés de tentar responder com um sim ou não, nós tentamos compreender melhor a própria pergunta. Concluímos que essa controvérsia não é apenas uma questão de definições, pois ainda não existe um fundamento epistemológico comum (ou visão de mundo) entre as ciências naturais e sociais que pudesse sustentar uma definição consensual. Acreditamos que a síntese é possível, mas a busca por uma abordagem consensual deverá levar a uma ampla reconstrução epistêmica que provavelmente exigirá, dos interessados a participar dessa reconstrução, a habilidade de dialogar com outros autores, dos quais divergem talvez não apenas em termos das teorias advogadas, mas, mais fundamental, em termos de visão de mundo e dos compromissos, preconceitos e motivações pessoais.

\section{Referências}

Barnard, A., \& Spencer, J. (2005). Culture. In A. Barnard \& J. Spencer (Orgs.), Encyclopedia of social and cultural anthropology (pp. 136-143). Londres: Routledge.

Boas, F. (1940). Race, language and culture. Nova Iorque: Macmillan.

Boesch, C. (1991). Teaching in wild chimpanzees. Animal Behaviour, 41(3), 530-532.

Boesch, C., \& Boesch, H. (1981). Sex differences in the use of natural hammers by wild chimpanzees: A preliminary report. Journal of Human Evolution, 10, 585-593.

Boesch, C., \& Boesch, H. (1984). Possible causes of sex differences in the use of natural hammers by wild chimpanzees. Journal of Human Evolution, $13,415-440$.

Boesch, C., \& Boesch, H. (1989). Hunting behavior of wild chimpanzees in the Tai' National Park. American Journal of Physical Anthropology, 78, 547-573.

Dawkins, R. (1989). The selfish gene (New Edition). Oxford: Oxford University Press.

Descola, P., \& Pálsson, G. (1996). Introduction. In P. Descola \& G. Pálsson (Orgs.), Nature and society. Londres: Routledge.

Galef, B. G. (2006). Traditions in animals. In K. Brown (Org.), Encyclopedia of language and linguistics (vol. 12, pp. 12-15). Oxford: Elsevier.

Geertz, C. (1973). The interpretation of cultures: Selected essays by Clifford Geertz. Nova Iorque: Basic Books.

Gibson, J. J. (1979). The ecological approach to visual perception. Boston: Houghton Mifflin.

Goodall, J. (1964). Tool-using and aimed throwing in a community of free-living chimpanzees. Nature, 201, 1264-1266.

Gottlieb, G. (1992). Individual development and evolution: The genesis of novel behavior. Nova Iorque: Oxford University Press.

Grant, B. R., \& Grant, P. R. (1996). Cultural inheritance of song and its role in the evolution of Darwin's finches. Evolution, 50(6), 2471-2487.

Griffiths, P. E., \& Gray, R. D. (1994). Developmental systems and evolutionary explanation. Journal of Philosophy, 91, 277-304.

Hinde, R. A. (1988). Individuals, relationships and culture: Links between Ethology and the Social Sciences (Themes in the Social Sciences). Cambridge: Cambridge University Press.

Hirata, S., Watanabe, K., \& Kawai, M. (2001). "Sweet-potato washing" revisited. In T. Matsuzawa (Org.), Primate origins of human cognition and behavior (pp. 487-508). Tokyo: Springer.

Imanishi, K. (2002). The world of living things. In P. Asquith (Org.), A Japanese view of nature. Nova Iorque: Routledge Curzon. (Obra original publicada em 1941)

Ingold, T. (1998). The evolution of society. In A. C. Fabian (Org.), Evolution: Society, science and the universe (pp. 79-99). Cambridge: Cambridge University Press.

Ingold, T. (2000). The perception of the environment: Essays on livelihood, dwelling and skill. Londres: Routledge.

Ingold, T. (2004). Beyond biology and culture: The meaning of evolution in a relational world. Social Anthropology, 12(2), 209-221.

Jablonka, E., \& Lamb, M. J. (2005). Evolution in four dimensions: Genetic, epigenetic, behavioral and symbolic variation in the history of life. Cambridge: MIT Press.

Kawai, M. (1965). Newly-acquired pre-cultural behavior of the natural troop of Japanese monkeys on Koshima Islet. Primates, 6, 1-30.

Kawamura, S. (1959). The process of sub-culture propagation among Japanese macaques. Primates, 2, 43-60.

Kroeber, A. L. (1917). The superorganic. American Anthropologist (New Series), 19(2), 163-213.

Kroeber, A. L., \& Kluckhohn, C. (1952). Culture: A critical review of concepts and definitions. (n. 1, Vol. 47). Cambridge: Peabody Museum.

Kuo, Z.-Y. (1967). The dynamics of behavioral development. Nova Iorque: Random House.

Laland, K. N., \& Galef, B. G. (Orgs.) (2009). The question of animal culture. Cambridge: Harvard University Press.

Latour, B. (1993). We have never been modern. Cambridge: Harvard University Press.

Lehrman, D. S. (1953). A critique of Konrad Lorenz's theory of instinctive behavior. Quaterly Review of Biology, 28, 337-363.

Lévi-Strauss, C. (1974). Structural Anthropology. Nova Iorque: Basic Books. (Obra original publicada em 1952)

Lewontin, R. C. (1983). Gene, organism, and environment. In D. S. Bendall (Org.), Evolution: from molecules to men (pp. 273-285). Cambridge: Cambridge University Press. 
Matsuzawa, T. (2003). Koshima monkeys and Bossou chimpanzees: Long-term research on culture in non-human primates. In F. B. M. De Waal \& P. L. Tyack (Orgs.), Animal Social Complexity: Intelligence, Culture and Individualized societies (pp. 374-387). Cambridge: Harvard University Press.

McGrew, W. C. (1992). Chimpanzee material culture: Implications for human evolution. Cambridge: Cambridge University Press.

McGrew, W. C. (2003). Ten dispatches from the chimpanzee culture wars. In F. B. de Waal \& P. L. Tyack (Orgs.), Animal social complexity: Intelligence, culture and individualized societies (pp. 419-439). Cambridge: Harvard University Press.

McGrew, W. C. (2004). The cultured chimpanzee: Reflections on cultural primatology. Cambridge: Cambridge University Press.

McGrew, W. C., \& Tutin, C. E. G. (1978). Evidence for a social custom in wild chimpanzees? Man, 13(2), 234-251. doi: 10.2307/2800247

Nakamura, M., \& Nishida, T. (2006). Subtle behavioral variation in wild chimpanzees, with special reference to Imanishi's concept of kaluchua. Primates, 47, 35-42.

Nishida, T. (1968). The social group of wild chimpanzees in the Mahali Mountains. Primates, 9, 167-224.

Nishida, T. (1987). Local traditions and cultural transmission. In B. Smuts, D. L. Cheney, R. M. Seyfarth, R. W. Wrangham, \& T. T. Struhsaker (Orgs.), Primate societies (pp. 462-474). Chicago: University of Chicago Press.

Odling-Smee, F. J. (2007). Niche inheritance: A possible basis for classifying multiple inheritance systems in evolution. Biological Theory, 2(3), 276-289.

Odling-Smee, F. J., Laland, K. N., \& Feldman, M. W. (1996). Niche construction. American Naturalist, 147, 641-648.

Odling-Smee, F. J., Laland, K. N., \& Feldman, M. W. (2003). Niche construction: The neglected process in evolution (monographs in population biology) (Vol.

37). Princeton: Princeton University Press.

Oyama, S. (1985). The ontogeny of information: Developmental systems and evolution. Cambridge: Cambridge University Press.

Oyama, S. (2000). Evolution's eye: A systems view of the biology-culture divide. Durham: Duke University Press.

Oyama, S., Griffiths, P. E., \& Gray, R. D. (Orgs.). (2001). Cycles of contingency: Developmental systems and evolution. Cambridge: MIT Press.

Pagnotta, M. (2012). A atribuição de cultura a primatas não humanos: a controvérsia e a busca por uma abordagem sintética (Dissertação de Mestrado). Universidade de São Paulo. Recuperado de http://www.teses. usp.br/teses/disponiveis/47/47132/tde-25072012-092135/

Rendell, L., \& Whitehead, H. (2001). Culture in whales and dolphins. Behavioral and Brain Sciences, 24, 309-382.

Schneirla, T. C. (1956). Interrelationships of the "innate" and the "acquired" in instinctive behavior. In P.-P. Grasse (Org.), L'instinct dans le comportement des animaux et de l'homme (pp. 387-452). Paris: Masson.

Tylor, E. B. (1874). Primitive Culture: Researches into the development of mythology, philosophy, religion, language, art and customs. Nova Iorque: H. Holt and Company. (Obra original publicada em 1871)

Van Schaik, C. P., Ancrenaz, M., Borgen, G., Galdikas, B., Knott, C. D., Singleton, I., ... Merrill, M. (2003). Orangutan cultures and the evolution of material culture. Science, 299, 102-105. doi: 10.1126/science.1078004

Washburn, S. L., \& Benedict, B. (1979). Non-human primate culture. Man (New Series), 14(1), 163-164.

White, L. (1949). The Science of culture: A study of man and civilization. Nova Iorque: Grove Press.

Whiten, A., Goodall, J., McGrew, W. C., Nishida, T., Reynolds, V., Sugiyama, ... Boesch, C. (1999). Cultures in chimpanzees. Nature, 399, 682-685. doi: $10.1038 / 21415$

Williams, R. (1983). Culture. In: R. Williams (Org.), Keywords: A vocabulary of culture and society (Ed. rev., pp. 87-93). Nova Iorque: Oxford University Press.

Murillo Pagnotta, Mestre em Psicologia Experimental pela Universidade de São Paulo (USP).

Endereço para correspondência: Av. Prof. Mello Moraes, 1721 - CEP 05508-030, Cidade Universitária - São

Paulo - SP. Telefone: 3091-4358. Email: murillopagnotta@usp.br

Briseida Dogo de Resende, Pós doutora em Psicologia Experimental pela Universidade de São Paulo (USP), Doutora em Psicologia Experimental pela Universidade de São Paulo (USP), é professora doutora no Instituto de Psicologia da Universidade de São Paulo (IP USP). Email: briseida@usp.br 